\title{
Clinical course and treatment of venereal spirochaetosis in New Zealand white rabbits
}

\author{
RONALD F DIGIACOMO,* SHEILA A LUKEHART, + CHARLES D TALBURT, \\ SHARON A BAKER-ZANDER, † JUDY CONDON, * AND CHARLES W BROWN \\ From the *Division of Animal Medicine and the + Department of Medicine, School of Medicine, \\ University of Washington, and the $¥ P$ Public Health Laboratories, Health Services Division, Department of \\ Social and Health Services, State of Washington, Seattle, Washington, USA
}

SUMMARY Ten sporadic cases of venereal spirochaetosis, caused by Treponema paraluiscuniculi, were seen in New Zealand white rabbits in two years. An equal number of males and females were affected. Females tended to have milder clinical signs than males. Lesions were usually found on the prepuce in males and the vulva in females, although the anus and skin of the perineum were also affected. Facial lesions were rare. Lesions healed in seven to 28 days in rabbits treated with penicillin. Eight rabbits had antibodies reactive in the Venereal Disease Research Laboratory (VDRL), rapid plasma reagin (RPR), and fluorescent treponemal antibody absorbed (FTA-ABS) tests when the disease was first diagnosed. In several rabbits followed longitudinally, RPR test results became negative two to four months after antimicrobial treatment, VDRL antibody titres diminished but usually persisted at low levels, while FTA-ABS antibodies declined slowly and were still evident 12 months after treatment.

\section{Introduction}

Penicillin is the drug of choice for treating infection with Treponema pallidum in man. ${ }^{1}$ It is also effective in treating experimental infections with $T$ pallidum in rabbits, but treatment regimens vary. ${ }^{2}$ Penicillin was recently reported to have eliminated clinical and serological evidence of infection with Treponema paraluis-cuniculi in rabbits. ${ }^{3}$ In man, reagin antibodies disappear after treatment of early syphilis while treponemal antibodies usually persist, often for life. ${ }^{14}$ This study describes the clinical course of naturally occurring venereal spirochaetosis, and the non-treponemal and treponemal antibody responses to $T$ paraluis-cuniculi, before and after treating infected New Zealand white rabbits with penicillin.

\section{Materials and methods}

ANIMALS

Adult male and female New Zealand white rabbits of varying ages were obtained from four different local commercial rabbitries. Rabbits were housed individually in stainless steel cages with wire floors. The

Address for reprints: Dr $\mathbf{R}$ DiGiacomo, Division of Animal Medicine, SB-42, School of Medicine, University of Washington, Seattle, WA 98195, USA

Accepted for publication 6 January 1984 lighting cycle was 12 hours of illumination and 12 hours of darkness. Commercial feed and water were available ad libitum. Room temperature was maintained at $18-24^{\circ} \mathrm{C}$, relative humidity was $40-50 \%$, and the rooms were ventilated at a rate of 12 air changes an hour. Rabbits with venereal spirochaetosis were treated with procaine penicillin $G$ or a combined preparation of procaine and benzathine penicillin G.

\section{CLINICAL SPECIMENS}

Cutaneous lesions were abraded with sterile gauze soaked with $0.9 \%$ saline. Serum from lesions was expressed on to glass slides. Smears for dark field microscopy were mounted with a cover slip, placed in a moisturised chamber, and examined immediately. Smears for fluorescent antibody dark field examination were air dried, fixed, and stained as described previously. ${ }^{5} T$ pallidum (Nichols strain) was used as a positive control. Tissues from rabbits examined post mortem were fixed in $10 \%$ formalin buffered with $2 \%$ sodium acetate, sectioned at $6 \mu \mathrm{m}$, and stained with haematoxylin and eosin.

\section{SEROLOGICAL TESTS}

Blood was collected from the marginal ear vein, allowed to clot in vacutainer tubes without anticoagulant, centrifuged, and the serum was removed. 
All serological tests were performed as described in the Manual of tests for syphilis. ${ }^{6}$ A quantitative Venereal Disease Research Laboratory (VDRL) slide test was performed using commercially obtained reagent (Difco Laboratories, Detroit, Michigan, USA). The rapid plasma reagin (RPR) card test was performed using a commercial kit (Kit No 110, Hynson, Wescott, \& Dunning, Baltimore, Maryland, USA). Bactosyphilitic serum 4 + (Difco) was used as the positive (reactive) control. The fluorescent treponemal antibody absorbed (FTA-ABS) test was performed as described. Serum was diluted in sorbent in a ratio of 1/5; further dilutions were made in phosphate buffered saline. $T$ pallidum (Nichols strain) antigen smears were covered with $0.03 \mathrm{ml}$ of test serum dilutions. After the smears were rinsed, goat anti rabbit IgG (at a dilution of $1 / 1600$ ) conjugated with fluorescein isothiocyanate (Cappel Laboratories, Cochranville, USA) was added to each smear. Reactive control serum was obtained from rabbits experimentally infected with $T$ pallidum or $T$ paraluis-cuniculi. Negative control serum (normal rabbit serum) was obtained from rabbits giving no reactions to RPR and VDRL tests. Results were expressed as the highest dilution of serum giving a $2+$ degree of fluorescence. ${ }^{?}$

\section{LYMPHOCYTE TRANSFORMATION}

Lymphocytes were obtained from heparinised blood by Ficoll-Hypaque separation, washed in balanced salt solution, and placed in microculture as described previously. ${ }^{8}$ Sonicated $T$ pallidum (Nichols strain) organisms were used as the treponemal antigen at a concentration of $50 \times 10^{6} / \mathrm{ml}$. Concanavalin A (Con A), a rabbit $T$ cell mitogen, (Miles Laboratories, Elkhart, Indiana, USA) was used at a concentration of $5-10 \mathrm{mg} / \mathrm{l}$. Cultures were pulsed with $0 \cdot 1 \mu \mathrm{Ci}$ ${ }^{125} \mathrm{I}$-iododeoxyuridine for 24 hours, and the results obtained represent the counts per minute (cpm) incorporated by $0.25 \times 10^{6}$ lymphocytes. The geometric mean of six replicate cultures for each sample was calculated and the background results for unstimulated cultures (approximately 50 to $450 \mathrm{cpm}$ ) were subtracted. The stimulation index was calculated by dividing the mean result for $T$ pallidum or Con A stimulation by the mean for unstimulated cultures. The mean stimulation index of lymphocytes from five normal rabbits was 1.5 (range 1.0 to 1.8 ) for $T$ pallidum and 92.9 (range $61 \cdot 5$ to $147 \cdot 0$ ) for Con A.

\section{Results}

During a two year period from April 1979 to March 1981 we found 10 clinical cases of venereal spirochaetosis in rabbits obtained from commercial rabbitries in Washington and maintained in the animal facility of the University of Washington (table I). Cases occurred sporadically, five males and five females being affected. These rabbits had been maintained in the animal facility for one to 1009 days before the diagnosis was made. Two cases were diagnosed on the day after arrival, and four between days 66 and 117 after arrival. These six rabbits had no known contact with other rabbits in the animal facility. In four other rabbits, which were being mated as part of an experimental study, venereal spirochaetosis was diagnosed 57 to 1009 days after their arrival.

Table I shows that genital lesions were seen in all cases. The prepuce of males and the vulva of females were most often affected. In some rabbits the anus and skin of the perineum were also affected, and facial lesions occurred in one rabbit. Lesions varied from erythematous slightly raised papules to large papillary nodules in the skin, and were occasionally more diffuse, reddened, and scaly. They progressed to an eroded appearance, wept serum, and formed crusts. Females tended to have milder clinical manifestations than males. The diagnosis of venereal

TABLE I Cases of venereal spirochaetosis in 10 New Zealand rabbits

\begin{tabular}{|c|c|c|c|c|c|c|c|c|}
\hline No & Sex & $\begin{array}{l}\text { Weight } \\
(\mathrm{kg})\end{array}$ & $\begin{array}{l}\text { Days in } \\
\text { colony }\end{array}$ & $\begin{array}{l}\text { Rabbit } \\
\text { contact } \\
\text { in colony }\end{array}$ & \multicolumn{2}{|c|}{ Clinical disease } & \multicolumn{2}{|c|}{ Diagnostic tests } \\
\hline $\begin{array}{l}941 \\
932 \\
\text { ID } \\
144 \\
581 \\
151 \\
342 \\
783 \\
785 \\
8 D\end{array}$ & $\begin{array}{l}M \\
M \\
F \\
F \\
F \\
F \\
M \\
M \\
M \\
F\end{array}$ & $\begin{array}{l}3 \cdot 4 \\
2 \cdot 6 \\
3 \cdot 3 \\
3 \cdot 2 \\
2 \cdot 4 \\
3 \cdot 5 \\
3 \cdot 0 \\
4 \cdot 3 \\
4 \cdot 0 \\
4 \cdot 2\end{array}$ & $\begin{array}{r}117 \\
85 \\
102 \\
66 \\
1009 \\
1 \\
57 \\
492 \\
496 \\
1\end{array}$ & $\begin{array}{l}\text { No } \\
\text { No } \\
\text { No } \\
\text { No } \\
\text { Yes } \\
\text { No } \\
\text { Yes } \\
\text { Yes } \\
\text { Yes } \\
\text { No }\end{array}$ & $\begin{array}{l}\text { Moderate* } \\
\text { Severe† } \\
\text { Mild } \\
\text { Mild } \\
\text { Moderate } \\
\text { Mild } \\
\text { Moderate } \\
\text { Severe } \\
\text { Moderate } \\
\text { Moderate }\end{array}$ & $\begin{array}{l}\text { Prepuce, lips, nares } \\
\text { Prepuce, anus, perineal skin } \\
\text { Vulva } \\
\text { Vulva } \\
\text { Vulva } \\
\text { Vulva } \\
\text { Prepuce, anus } \\
\text { Prepuce, perineal skin } \\
\text { Prepuce, anus, perineal skin } \\
\text { Perineal skin }\end{array}$ & $\begin{array}{l}\text { NT } \\
\text { NT } \\
\text { NT } \\
\text { NT } \\
\text { NT } \\
+ \\
+ \\
+ \\
+ \\
+\end{array}$ & $\begin{array}{l}\text { NT } \\
\text { NT } \\
\text { NT } \\
\text { NT } \\
\text { NT } \\
+ \\
+ \\
+ \\
\text { NT } \\
+ \\
+\end{array}$ \\
\hline
\end{tabular}

DF = dark field examination; FADF = fluorescent antibody dark field examination;

"Killed one day after diagnosis; +Killed 10 days after diagnosis; $+=$ positive test results; NT = not tested. 
spirochaetosis was confirmed in $50 \%$ of the cases by finding treponemes on dark field and fluorescent antibody dark field microscopy of exudate from lesions. Two rabbits with active disease, which had not been tested by dark field or fluorescent antibody dark field microscopy, were examined post mortem. On histopathological examination, both rabbits had acute ulcerative balanoposthitis and purulogranulomatous lymphadenitis of regional lymph nodes, which were consistent with venereal spirochaetosis caused by $T$ paraluis-cuniculi. No lesions were seen in the testes.

Eight rabbits were treated with penicillin, and two were not treated. One untreated rabbit was killed the day after diagnosis, and one treated rabbit was killed 10 days after diagnosis. Four rabbits were given procaine penicillin $G(50000 \mathrm{U} / \mathrm{kg})$ once daily for seven to 14 days, while four were given procaine and benzathine penicillin $\mathrm{G}(50000 \mathrm{U} / \mathrm{kg})$ once weekly for three to four weeks. Lesions in seven of the treated rabbits healed in seven to 28 days. Lesions persisted for $\mathbf{7 2}$ days in the untreated rabbit.

Eight of the 10 rabbits gave positive reactions to all three serological tests when venereal spirochaetosis was diagnosed. Serum from the other two gave negative reactions to all serological tests, even when tested at a 1/8 dilution in the RPR and VDRL tests to rule out prozone phenomena. VDRL titres at the time of diagnosis ranged from $1 / 1$ to $1 / 8$, RPR titres from $1 / 1$ to $1 / 32$, and FTA-ABS titres from $1 / 32$ to $1 / 256$. Table II shows test results in five rabbits (one untreated and four treated) that were followed for five to 12 months after venereal spirochaetosis had been diagnosed. In the treated rabbits results of the RPR test became negative two to four months after treatment. VDRL titres also declined but persisted in two of the treated rabbits. FTA-ABS titres declined slowly, but persisted in all four treated rabbits. The figure shows that, in contrast, antibody titres in the untreated rabbit (8D) rose steadily over three months, declining only after clinical remission of venereal spirochaetosis. The antibody responses in rabbit 301, which had serological evidence of previous infection with $T$ paraluis-cuniculi but not of clinical venereal spirochaetosis and was considered to be chronically infected, is shown for comparison. Male rabbits 342, 783, and 785 were being bred with proved females as part of an experimental study. Several months after treatment and the fall in reagin levels, all rabbits had a fourfold rise in antibody titres in the FTA-ABS test and a return of reactivity in reagin tests (table II). No clinical evidence of venereal spirochaetosis was seen, however.

Peripheral blood lymphocytes in the untreated rabbit were assayed for responsiveness to treponemal antigens by the uptake of ${ }^{125}$ I-iododeoxyuridine. The figure shows that the stimulation index was $3 \cdot 2$ five weeks after diagnosis of venereal spirochaetosis, $2 \cdot 4$ at 10 weeks, and 1.1 at 22 weeks. In contrast, the stimulation index of blood lymphocytes from rabbit 301, which had chronic infection, was $1 \cdot 3$ at 6 weeks and $1 \cdot 1$ at 24 weeks.

\section{Discussion}

The onset of venereal spirochaetosis in four unexposed rabbits nine to 17 weeks after they entered the animal facility suggests a considerably longer incubation period than the two to eight weeks commonly cited. ${ }^{9}$ Studies of vertical transmission

TABLE II Serological responses in five New Zealand rabbits with naturally acquired infection with Treponema paraluiscuniculi

Highest dilutions of serum giving positive results (months after diagnosis)

\begin{tabular}{|c|c|c|c|c|c|c|c|c|c|c|c|c|c|c|}
\hline \multirow[b]{2}{*}{ No } & \multirow[b]{2}{*}{ Test } & & & & & & & & & & & & & \\
\hline & & 0 & 1 & 2 & 3 & 4 & 5 & 6 & 7 & 8 & 9 & 10 & $I I$ & 12 \\
\hline $8 D^{*}$ & $\begin{array}{l}\text { VDRL } \\
\text { RPR } \\
\text { FTA-ABS }\end{array}$ & $\begin{array}{l}1 / 2 \\
1 / 1 \\
1 / 16\end{array}$ & $\begin{array}{l}1 / 4 \\
1 / 2 \\
1 / 32\end{array}$ & $\begin{array}{l}1 / 4 \\
1 / 2 \\
1 / 32\end{array}$ & $\begin{array}{l}1 / 4 \\
1 / 4 \\
1 / 256\end{array}$ & $\begin{array}{l}1 / 8 \\
1 / 4 \\
1 / 64\end{array}$ & $\begin{array}{l}1 / 8 \\
1 / 4 \\
1 / 64\end{array}$ & $\begin{array}{l}\text { NT } \\
\text { NT } \\
\text { NT }\end{array}$ & $\begin{array}{l}\text { NT } \\
\text { NT } \\
\text { NT }\end{array}$ & $\begin{array}{l}\text { NT } \\
\text { NT } \\
\text { NT }\end{array}$ & $\begin{array}{l}\text { NT } \\
\text { NT } \\
\text { NT }\end{array}$ & $\begin{array}{l}\text { NT } \\
\text { NT } \\
\text { NT }\end{array}$ & $\begin{array}{l}\text { NT } \\
\text { NT } \\
\text { NT }\end{array}$ & $\begin{array}{l}\text { NT } \\
\text { NT } \\
\text { NT }\end{array}$ \\
\hline 785† & $\begin{array}{l}\text { VDRL } \\
\text { RPR } \\
\text { FTA-ABS }\end{array}$ & $\begin{array}{l}1 / 2 \\
1 / 2 \\
1 / 64\end{array}$ & $\begin{array}{l}1 / 1 \\
1 / 1 \\
1 / 8\end{array}$ & $\begin{array}{l}- \\
\overline{1 / 2}\end{array}$ & $\begin{array}{l}- \\
\overline{1 / 2}\end{array}$ & $\begin{array}{l}- \\
\overline{1 / 2}\end{array}$ & $\begin{array}{l}- \\
- \\
1 / 1\end{array}$ & $\begin{array}{l}- \\
\overline{1 / 4}\end{array}$ & $\begin{array}{l}1 / 1 \\
1 / 4 \\
1 / 8\end{array}$ & $\begin{array}{l}\text { NT } \\
\text { NT } \\
\text { NT }\end{array}$ & $\begin{array}{l}\text { NT } \\
\text { NT } \\
\text { NT }\end{array}$ & $\begin{array}{l}\text { NT } \\
\text { NT } \\
\text { NT }\end{array}$ & $\begin{array}{l}\text { NT } \\
\text { NT } \\
\text { NT }\end{array}$ & $\begin{array}{l}\text { NT } \\
\text { NT } \\
\text { NT }\end{array}$ \\
\hline $783+$ & $\begin{array}{l}\text { VDRL } \\
\text { RPR } \\
\text { FTA-ABS }\end{array}$ & $\begin{array}{l}1 / 8 \\
1 / 32 \\
1 / 128\end{array}$ & $\begin{array}{l}1 / 2 \\
1 / 4 \\
1 / 64\end{array}$ & $\begin{array}{l}1 / 1 \\
1 / 1 \\
1 / 16\end{array}$ & $\begin{array}{l}- \\
1 / 1 \\
1 / 16\end{array}$ & $\begin{array}{l}- \\
\overline{1 / 16}\end{array}$ & $\begin{array}{l}- \\
\overline{1} / 2\end{array}$ & $\begin{array}{l}- \\
1 / 1 \\
1 / 16\end{array}$ & $\begin{array}{l}1 / 2 \\
1 / 1 \\
1 / 256\end{array}$ & $\begin{array}{l}\text { NT } \\
\text { NT } \\
\text { NT }\end{array}$ & $\begin{array}{l}\text { NT } \\
\text { NT } \\
\text { NT }\end{array}$ & $\begin{array}{l}\text { NT } \\
\text { NT } \\
\text { NT }\end{array}$ & $\begin{array}{l}\text { NT } \\
\text { NT } \\
\text { NT }\end{array}$ & $\begin{array}{l}\text { NT } \\
\text { NT } \\
\text { NT }\end{array}$ \\
\hline $342+$ & $\begin{array}{l}\text { VDRL } \\
\text { RPR } \\
\text { FTA-ABS }\end{array}$ & $\begin{array}{l}1 / 8 \\
1 / 32 \\
1 / 128\end{array}$ & $\begin{array}{l}1 / 2 \\
1 / 1 \\
1 / 32\end{array}$ & $\begin{array}{l}1 / 2 \\
- \\
1 / 64\end{array}$ & $\begin{array}{l}1 / 1 \\
- \\
1 / 32\end{array}$ & $\begin{array}{l}1 / 1 \\
1 / 1 \\
1 / 256\end{array}$ & $\begin{array}{l}\text { NT } \\
\text { NT } \\
\text { NT }\end{array}$ & $\begin{array}{l}1 / 2 \\
1 / 2 \\
1 / 256\end{array}$ & $\begin{array}{l}1 / 2 \\
1 / 1 \\
1 / 128\end{array}$ & $\begin{array}{l}1 / 2 \\
1 / 2 \\
1 / 128\end{array}$ & $\begin{array}{l}1 / 8 \\
1 / 1 \\
1 / 256\end{array}$ & $\begin{array}{l}1 / 4 \\
1 / 1 \\
1 / 256\end{array}$ & $\begin{array}{l}1 / 4 \\
1 / 1 \\
1 / 256\end{array}$ & $\begin{array}{l}1 / 4 \\
1 / 1 \\
1 / 256\end{array}$ \\
\hline 1D & $\begin{array}{l}\text { VDRL } \\
\text { RPR } \\
\text { FTA-ABS }\end{array}$ & $\begin{array}{l}1 / 4 \\
1 / 4 \\
1 / 64\end{array}$ & $\begin{array}{l}1 / 2 \\
1 / 1 \\
1 / 32\end{array}$ & $\begin{array}{l}\text { NT } \\
\text { NT } \\
\text { NT }\end{array}$ & $\begin{array}{l}1 / 1 \\
- \\
1 / 4\end{array}$ & $\begin{array}{l}\text { NT } \\
\text { NT } \\
\text { NT }\end{array}$ & $\begin{array}{l}1 / 1 \\
\overline{1} \\
1 / 8\end{array}$ & $\begin{array}{l}1 / 1 \\
\frac{1}{1 / 16}\end{array}$ & $\begin{array}{l}\frac{1 / 1}{1 / 8} \\
\frac{-}{1 / 8}\end{array}$ & $\begin{array}{l}- \\
\overline{1 / 4}\end{array}$ & $\begin{array}{l}1 / 1 \\
- \\
1 / 4\end{array}$ & $\begin{array}{l}1 / 1 \\
- \\
1 / 2\end{array}$ & $\begin{array}{l}- \\
\overline{1 / 1}\end{array}$ & $\begin{array}{l}1 / 1 \\
1 / 1\end{array}$ \\
\hline
\end{tabular}

*Untreated rabbit, clinical remission in 2-3 months; the other four treated, clinical remission within one month; †rabbits in breeding study; VDRL = Venereal Disease Research Laboratory test; RPR = rapid plasma reagin test; FTA-ABS = fluorescent treponemal antibody absorbed test; - = negative test result; $\mathrm{NT}=$ not tested. 


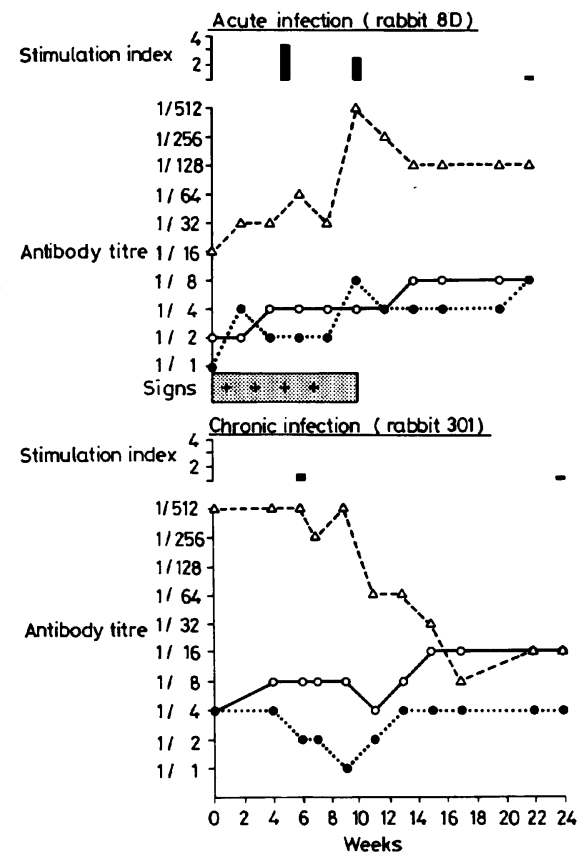

FIGURE Serological 10 = Venereal Disease Research Laboratory test, $=$ rapid plasma reagin test, $\Delta=$ fluorescent treponemal antibody absorbed test) and lymphocytic (stimulation index) response to naturally acquired infection with Treponema paraluis-cuniculi in female New Zealand white rabbits. Rabbit $8 D$ had clinical signs of venereal spirochaetosis (box indicates positive results on dark field and fluorescent antibody dark field microscopy), while rabbit 301 was clinically normal.

have shown that newborn rabbits from infected dams, which were fostered with non-infected dams within 24 hours after birth, showed clinical and serological evidence of venereal spirochaetosis at 14 to 16 weeks. ${ }^{10}$ Fostering newborn rabbits from noninfected with infected dams resulted in the onset of venereal spirochaetosis at 12 weeks, whereas newborn rabbits left with infected dams developed venereal spirochaetosis at about 10 weeks. Rabbits obtained by hysterectomy of infected dams failed to develop venereal spirochaetosis. This indicates an incubation period of 10 to 16 weeks, which may be influenced by passively transferred maternal antibodies. In eight of the 10 affected rabbits, antibodies were present on VDRL, RPR, and FTA-ABS testing when the disease was diagnosed. As lesions usually precede the development of antibodies by two to six weeks, ${ }^{10}$ the disease may have been undetected for several weeks.

Rabbits with venereal spirochaetosis were treated with either procaine penicillin $G$ or procaine and benzathine penicillin $G$. Lesions healed in one to four weeks and antibodies were undetectable on RPR testing two to four months after treatment. Results of the VDRL test also became negative (or positive only with undiluted serum), but antibodies in the FTAABS test declined slowly and were still present one year after treatment. In efficacy studies using $\mathbf{4 2} 000$ and $84000 \mathrm{U} / \mathrm{kg}$ procaine and benzathine penicillin $\mathrm{G},{ }^{3}$ lesions in rabbits that were naturally infected with $T$ paraluis-cuniculi regressed within two weeks, and antibodies in the RPR test were usually undetectable about two months after treatment. In the absence of treatment, signs of venereal spirochaetosis usually persist for many weeks. In a clinical survey naturally infected rabbits had lesions for at least one to three months. ${ }^{11}$ Lesions persisted for several months in rabbits inoculated intradermally or subcutaneously with scrapings from lesions of naturally infected rabbits that were positive on dark field microscopy. ${ }^{10}$

The rise in serum antibodies in the three breeding rabbits suggests that successfully treated animals may be susceptible to reinfection, which may be subclinical. In experimental infection with $T$ palli$d u m$, rabbits whose "immunising infection" is cured with penicillin within three months, when resistance has not fully developed, can be consistently reinfected on challenge. 1213 Recrudescence of latent infection because of treatment failure was unlikely, as it has been shown that treatment of venereal spirochaetosis with penicillin resulted in no clinical relapses for at least 20 weeks after treatment. ${ }^{3}$

The curative dose of penicillin for experimental $T$ pallidum infection in rabbits is usually given as a single dose of $1 \cdot 2 \mathrm{MU}$ benzathine penicillin $\mathrm{G}$ administered intramuscularly. ${ }^{1214}$ Suspensions from the chancres of rabbits with primary syphilis, which were obtained three to 48 hours after treatment with a single dose of $84000 \mathrm{U} / \mathrm{kg}$ benzathine penicillin, failed to produce chancres or seroconversion in healthy rabbits. ${ }^{15}$ In addition, popliteal lymph nodes from rabbits treated with 50000 to $200000 \mathrm{U} / \mathrm{kg}$ benzathine penicillin, and transferred during latent syphilis were not infectious for the recipients. ${ }^{4} 131516$ It was recently shown that three weekly injections of either 42000 or $84000 \mathrm{U} / \mathrm{kg}$ procaine and benzathine penicillin $\mathbf{G}$ eliminated clinical and serological evidence of naturally acquired $T$ paraluis-cuniculi infection in rabbits. ${ }^{3}$ Our study gave similar results with three weekly injections of $50000 \mathrm{U} / \mathrm{kg}$ procaine and benzathine penicillin $G$ in rabbits with venereal spirochaetosis. 
This study was supported in part by grants RR01203 from the Division of Research Resources and AI12192 from the National Institute of Allergy and Infectious Diseases, National Institutes of Health, Bethesda, Maryland. S A Lukehart was the recipient of a venereal diseases research fund postdoctoral fellowship from the American Social Health Association. We thank the several investigators who provided periodic blood samples from rabbits and James Farley and Cheryl Stevens for their excellent technical assistance.

\section{References}

1. Sparling PF. Diagnosis and treatment of syphilis. $N$ Engl $J$ Med 1971;284:642-53.

2. Turner TB, Hollander DH. Biology of the treponematoses. WHO Monogr Ser 1957; No 35.

3. Cunliffe-Beamer TL, Fox RR. Venereal spirochetosis of rabbits: eradication. Lab Anim Sci 1981;31:379-81.

4. Yobs AR, Clark JW Jr, Mothershed SE, Bullard JC, Artley $\mathrm{CW}$. Further observations on the persistence of Treponema pallidum after treatment in rabbits and humans. Br J Vener Dis $1968 ; 44: 116-30$

5. Wood RM. Tests for syphilis. In: Rose NR, Friedman H, eds. Manual of clinical immunology. Washington DC: American Society for Microbiology, 1976;349-50.

6. US Public Health Service. Manual of tests for syphilis - 1969. Washington DC: US Government Printing Office 1969; (PHS Publication No 411).
7. Lukehart SA, Baker-Zander SA, Lloyd RMC, Sell S. Effect of cortisone administration on host-parasite relationships in early experimental syphilis. $J$ Immunol 1981;127:1361-8.

8. Lukehart SA, Baker-Zander SA, Sell S. Characterization of lymphocyte responsiveness in early experimental syphilis. I. In vitro response to mitogens and Treponema pallidum antigens. $J$ Immunol 1980; 124:454-60.

9. Wilson GS, Miles A. Topley and Wilson's Principles of Bacteriology and Immunity Vol II. Baltimore: Williams \& Wilkins, 1975.

10. Cunliffe-Beamer TL, Fox RR. Venereal spirochetosis of rabbits: epizootiology. Lab Anim Sci 1981;31:372-8.

11. Cunliffe-Beamer TL, Fox RR. Venereal spirochetosis of rabbits: description and diagnosis. Lab Anim Sci 1981;31: 366-71.

12. Miller JN, Fazzan FP, Whang SJ. Studies on immunity in experimental syphilis. II. Treponema pallidum immobilization (TPI) antibody and the immune response. Br J Vener Dis 1963 ; 39: 199-203.

13. Ovcinnikov NM, Korbut SE, Bednova VN, Timcenko GF, Milonova TI. Long-term results of penicillin treatment of early and late forms of syphilis in the rabbit. BrJ Vener Dis 1973:49: 413-9.

14. Miller JN. The appearance and persistence of the VDRL, RPCF, and TPI antibody during the course and treatment of experimental syphilis in the rabbit. $J$ Invest Dermatol 1964;42: 367-71.

15. Ovcinnikov NM, Delektorskij VV. Effect of crystalline penicillin and bicillin-1 on experimental syphilis in the rabbit. Br J Vener Dis 1972;48:327-41.

16. Collart $P$, Borel LJ, Durel P. Significance of spiral organisms found, after treatment, in late human and experimental syphilis. Br J Vener Dis 1964;40:81-9. 